\title{
Impoliteness of Directive Speech Acts in Online Indonesian Language Learning
}

\author{
Laili Etika Rahmawati ${ }^{1 *}$, Nurul Hidayat ${ }^{2}$, Andra Kurniawan ${ }^{3}$ \\ Universitas Muhammadiyah Surakarta ${ }^{12}$, Universitas Sebelas Maret ${ }^{3}$
}

*Corresponding Author

Email: laili.Rahmawati@ums.ac.id

DOI: http://dx.doi.org/10.18326/jopr.v3i2.97-107

\section{Copyright (C) The Author (s)}

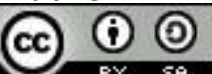

This work is licensed under a Creative Commons Attribution-ShareAlike 4.0 International License.

How to Cite: Rahmawati, L., Hidayat, N., \& Kurniawan, A. (2021). Impoliteness of Directive Speech Acts in Online Indonesian Language Learning. Journal of Pragmatics Research, 3(2). doi:https://doi.org/10.18326/jopr.v3i2.97-107

\begin{tabular}{|c|c|}
\hline $\begin{array}{l}\text { Submission } \\
\text { Track: } \\
\text { Received: } \\
\text { 01-03-2021 } \\
\text { Final Revision: } \\
\text { 21-05-2021 } \\
\text { Available online: } \\
\text { 01-10-2021 } \\
\text { Corresponding } \\
\text { Author: } \\
\text { Laili Etika Rahmawati } \\
\text { laili.Rahmawati@ums.ac.id }\end{array}$ & $\begin{array}{l}\text { ABSTRACT } \\
\text { This study aims to describe the impoliteness of directive speech acts in online Indonesian } \\
\text { language learning. The data collection technique in this study used the observation, } \\
\text { note, and record technique. The object of this research was the analysis of directive } \\
\text { speech act impoliteness. The data analysis technique used in this study was a data } \\
\text { triangulation model. The study results indicate an impoliteness of directive speech acts } \\
\text { on Indonesian language learning conducted by the teacher. The teacher unintentionally } \\
\text { performed impoliteness on the directive speech acts. The first data found that the } \\
\text { teacher asked all the students to pay attention impolitely. The second data showed that } \\
\text { the teacher as a speaker prohibits students from taking attendance. The third data } \\
\text { showed that the teacher used the impolite directive speech acts when saying the utter } \\
\text { "unnecessary" and "you pay less attention" to the students who forgot to attend the class. } \\
\text { The data (3a) above includes the impoliteness of the directive speech act of the } \\
\text { requesting because it does not contain politeness elements that can smooth speech. Data } \\
\text { (4a) The teacher asks students who are not members to leave the WhatsApp group, but } \\
\text { the teacher does not use soft sentences. Data (5a) stated that the teacher instructs the } \\
\text { students to cut the paper using a cutter and make lines on it . Next, the data (5b) } \\
\text { stated the teacher asks students to look at the learning material using impoliteness } \\
\text { directive speech acts. Data (5c) stated that the teacher instructs students not to forget } \\
\text { to fill the attendance. Data (6a) stated the teacher asks students to join the google } \\
\text { classroom but does not use polite sentences. The data includes the directive speech act } \\
\text { of the requesting marked with the word beg. Data (7a) Teachers require students to } \\
\text { have sufficient quotas when participating in learning Indonesian online. } \\
\text { Keywords: impoliteness, directive speech acts, Online learning }\end{array}$ \\
\hline
\end{tabular}




\section{INTRODUCTION}

Learning Indonesian language in schools is currently being carried out online due to the coronavirus pandemic, which has yet to be handled. Supriatna (2020) stated that the coronavirus, which first detected at the end of 2019, has yet to be handled entirely. The coronavirus that has hit this country has brought many changes to all Indonesian society sectors. One of the sectors which most affected is the education sector. Learning that was originally offline, now and then, has turned into online. Dewi (2020) stated that online learning is the use of internet networks in the learning process. Kahfi (2020) explains that media use can be considered attractive for interactive distance learning to arouse and inspire students' enthusiasm for learning. Still, in its implementation, there are many obstacles due to poor communication between teachers and students. According to Anugrahana (2020), online learning has become an interesting topic during the coronavirus pandemic. The learning process in the pandemic faced many problems, so solutions are needed to get a better education.

In carrying out online learning, teachers have done things such as ordering, asking, inviting, begging, offering, prohibiting, inviting, suggesting, and charging students to carry out what they are told. All of these things are called directive speech acts. Prayitno (2017) stated that directive speech acts basically to produce the effect of the actions taken by the speech partner. The use of directive speech acts conducted by the teacher greatly influenced the students' responses. Pérez Hernádez \& Ruiz De Mendoza (2002) have provided evidence that interactional aspects like politeness, optionality, speaker's relative power status, and degree of speaker's willingness are essential interpretations of several instances indirect requests. According to Tu \& McIsaac (2002), online or online communication will be different from off-network communication according to students 'understanding skills; if students' understanding is insufficient, proper communication will be difficult.

There is much impoliteness of directive speech acts conducted by the teacher when implementing Indonesian language online learning. In fact, the teacher did a lot of impoliteness in directive speech acts when online learning occurs in the WhatsApp group of teachers and students. Even though the teacher gave instructions or directions, they could influence student responses. Khair (2018) stated that learning Indonesian language is essentially giving lessons to students about sound and correct Indonesian language skills following their goals and functions. In achieving this, learning Indonesian online must be carried out optimally.

The impoliteness of directive speech acts in the education area from an early age must be eliminated. Fhitri (2018) revealed that impoliteness causes the target (speech partner) to feel uncomfortable. The directive speech acts actually could be carried out both directly or indirectly. 
Anyone could produce the impoliteness of directive speech acts at any time and anywhere. Impoliteness can occur in every environment, such as school, work, community, and government environments. Impoliteness is behavior that is face-aggravating in a particular context (Locher \& Bousfield, 2008). Impolite behavior, therefore, may be seen in terms of non-politic inappropriate behavior or non-polite behavior, which goes well beyond merely breaking socially-established norms and practices. Impoliteness comes about when (1): the speaker communicates face-attack intentionally, or (2) the hearer perceives and/or constructs behavior as intentionally face-attacking, or a combination of (1) and (2) (Mugford, 2008). Mai (2017) revealed the infinitival complements of rude words such as eavesdropping, interrupting, pointing, ignoring, and declining, actions that relate to unwarranted impositions or exclusions, other words, sociality rights.

Language impoliteness will follow because humans can only speak the language, and humans are creatures with thoughts, hearts, feelings, and emotions. This emotion is what often causes language impoliteness in various communications, including forbidden language. Indonesian language teachers should be able to use the correct directive speech acts well, but not all Indonesian language teachers can do it. The fact is that there still a lot of impoliteness in directive speech acts committed by Indonesian language teachers to their students. In the following discussion, we will discuss some impoliteness of directive speech acts carried out by Indonesian language teachers. An example of impoliteness in asking is "For students who are remedial to do this problem. Students who do not have a daily grade yet, contact my personal network". Things like that affect student responses because in the messages delivered by the teacher in the WhatsApp group there are no words of greetings children or say hello from the teacher to greet the students.

Communication most basically stands for the exchange of information (be it ideational or relational), "mediation" describes the fact that there is a technological means that is employed to communicate, and, finally, "computer" specifies that the means of mediation is related to technology, such as computers/internet, mobile phones, video conferencing, etc. In addition, it is useful to distinguish between synchronous means (e. g., chats) and asynchronous means (e. g., blogs, fora) of computer-mediated communication and to investigate both the situation and the technical factors that influence language practices (Locher, 2010). The current condition of the coronavirus pandemic requires the appropriate and wellbeing teachers in such matters, teachers encouraged to innovate in changing face-to-face learning patterns into non-face-to-face learning patterns. The obstacle, in this case, is the obstacle experienced by teachers amid this Coronavirus pandemic. At the same time, learning is carried out online and cannot be carried out face-to-face in the classroom. This condition requires teachers to innovate in the learning process, especially online (in the network). According to Hanum (2013), online learning or e-learning is a form of learning model facilitated and supported by the use of information and communication technology. The solution 
during the pandemic is to find solutions using network-based learning. In the end, teachers are required to be innovative in using online learning models. Online learning methods do not require students to attend the class. Instead, students can access the learning process through the internet media. Online network or online electronic learning, and some call it online learning is a learning activity that utilizes networks (internet, LAN, WAN) which consider as a method of delivery, interaction, and facilities and is supported by various other forms of learning services.

Indonesian language learning is divided into four language skills: listening, reading, speaking, and writing. In achieving these four aspects, the lesson must be implemented by using online learning media. Finally, the Indonesian language teachers must make better methods during this corona pandemic so that these four aspects can be adequately achieved.

\section{RESEARCH METHOD}

This study uses a qualitative approach. The qualitative design of this research is narrative research. The procedures for implementing this research consist of studying one or two individuals, gathering data through collecting their stories, reporting individual experiences, and chronologically ordering the meaning of those experiences (Creswell et al., 2007). Sudaryanto (2015) says that the qualitative approach method is an approach method that is solely based on facts or phenomena that empirically live in the speakers. Therefore, what is produced or recorded is in the form of data, as is it.

The data in this study are related to directive speech acts which contain elements of impoliteness in Indonesian language learning. The data collection of the impoliteness of directive speech acts was found at some WhatsApp group on Senior High Schools conducted by the Indonesian language teacher. In this study, the researcher used two data sources, namely primary and secondary data sources. The primary data source in this study is the impoliteness of directive speech acts in Indonesian language learning through the WhatsApp group and google classroom conducted by the teacher. Primary data sources were obtained directly by how the researcher entered the WhatsApp group for the class of teachers and students in Indonesian subjects. The secondary data source is obtained through intermediaries media or other sources such as YouTube channels.

The data in this study were collected using several techniques, including the observation technique. According to Sudaryanto (2015), the listening technique is an activity of listening to structures in writing. In the context of this study, the researcher listens to data on the indecency of directive speech acts in learning Indonesian language online. The listening technique was used to identify the data on the researcher's impoliteness of directive speech acts through the WhatsApp group during the Indonesian subjects conducted. The researcher also used the recording technique to record the impoliteness of directive speech acts in the WhatsApp group. It was performed by recording or taking screenshots to obtain the data. Finally, the note-taking technique was used to 
record the form of directive speech act impoliteness in learning Indonesian language online obtained through listening and note-taking techniques so that the researcher transcribed it into his language.

Data analysis began by reviewing the available data. The observations that have been carried out are then written in observation techniques, recording techniques, and note-taking techniques. The next step is analyzing the data carried out by the referential methods of change and equivalents whose determinants are part of the language concerned.

The validity of the data in this study used the triangulation method. Data triangulation involves using different sources of information to increase the validity of a study (Guion, 1969). In this study, the researcher used the data triangulation method. The available data were obtained from the WhatsApp groups of students and teachers. The data were sorted to fit the context impoliteness of directive speech acts in Indonesian language learning online.

\section{RESULTS \& DISCUSSION}

Speech acts performed in the utterance of a sentence are, in general, a function of the meaning of the sentence. The meaning of a sentence does not in all cases uniquely determine what speech act is performed in a given utterance of that sentence, for a speaker may mean more than what he actually says. Still, it is always in principle possible for him to say exactly what he means. Thus, the study of the meanings of sentences and the study of speech acts are not two independent studies but one study from two different perspectives (Searle, 1969).

Wijana (2021) stated that the speech act concerns any act of language speakers when delivering utterance. Concerning its category, it can be classified based on two criteria, i.e., focus and function of speech act. There are three types of speech act classification based on the focus. They are locutionary act (the act of saying something), illocutionary act (the act of doing something), and perlocutionary act (a speech act intended to affect anyone). Meanwhile, Syah et al. (Wijana, 2021) concentrated their study on using various directive speech act subcategories such as pleasing, requesting, asking, etc. These subcategories are very close to the directive speech act that would be the object of this study.

According to Prayitno (2017), directive speech acts are divided into 5 (five), including begging, asking/requesting, ordering, requiring, and prohibiting. Impoliteness of directive speech acts in learning Indonesian online has occurred a lot during this corona pandemic. Language impoliteness relates to the use of language that is not good and not in accordance with manners. Impoliteness in directive speech acts primarily occurs through the WhatsApp groups of teachers and students. The teacher consciously or unconsciously acts as well as impolitely directive speech acts. Suyanto \& Jihad (2013)argue that a professional teacher is a teacher with a unity of integrity and 
personality. The experienced teachers must also have good personalities and passions in the world of education.

The kinds of impoliteness of directive speech acts are various, such as asking/requesting, begging, ordering, inviting, welcoming, and prohibiting. Teachers in implementing teaching Indonesian language online are required to be familiar and kind to their students. Suyanto \& Jihad (2013) argue that teachers must always control their emotions when teaching students. The teachers sometimes do impoliteness of directive speech acts unconsciously. Several impolitenesses of directive speech acts occurred in Indonesian language learning online in several Senior High schools. Rahmatilah et al. (2017) stated that Indonesian Language Learning is one of the general subjects. Students have excellent and correct Indonesian language skills and can live with the Indonesian language and literature according to the situation, language goals, and experience level. Learning online is learning that utilizes internet technology. Online learning is a form of distance learning or more commonly abbreviated as PJJ. Every teacher has his/her way of carrying out online learning; some use Whatsapp group, Google Classroom, and Schoology. The teacher in delivering learning materials uses those media. The language used by the teacher in communicating with students through those media greatly affects students' interest in learning. Sugiarti et al. (2017) reveal that language plays an essential role in the lives of all components of society.

Humans use language as a tool to communicate. We often encounter language in the life community, i.e., at work meetings, meetings at the village office, and in the school environment. The use of language, especially during the learning process in the classroom, the teachers and the students often use official or formal language. The use of language in communication in the community and schools usually includes polite and impolite language. Interaction between speakers and listeners during a conversation or communication occurs mutually. The viewer or listener usually acts as the recipient of the information. Soon after receiving the information, the listener then understands the information to react to perform speech acts or become speakers.

On the other hand, the speaker who previously acted as an information giver after conveying the information would become the listener. Likewise, teachers and students in carrying out communication or conversations, there is always reciprocity in communicating. In this study, several directive speech acts include asking/requesting, prohibiting, offering, welcoming, ordering, begging, and requiring. The direct speech below is conveyed by the teacher as a speaker to the students as speech partners.

\section{The Impoliteness of Directive Speech Acts of Asking/Requesting}

The impoliteness of directive speech acts of asking/requesting is a speech act that implies asking the speech partner to be given something requested by the speech partner. Therefore, the 
directive's speech act of request aims to get something from the speech partner. Examples of impoliteness in directive request (asking) speech in Indonesian language learning through online by the teacher can be seen in the first data.

(1a) "Waktu pembelajaran setiap harinya dari pukul 07.00-14.00. tolong diperhatikan semuanya" (Do study every day start from 07.00-14.00. Please pay attention to all!)

(1b) "Tolong yang bisa menghubungi Nuri, tolong infokan hal ini padanya"

(Please who can contact Nuri, please inform her about this)

Data (1a) and (1b) are examples of impoliteness directive speech acts asking/requesting. Data (1a) the teacher demanding all students pay attention to the implementation time of Indonesian language lessons start from 07.00 to 14.00 . How to convey a message is classified as impoliteness because it does not call students "friends" or "children" which can be polite messages delivered to students. Data (1b) is also the same as data (1a); that is, neither use the words friends or children to convey messages to students.

\section{The Impoliteness of Directive Speech Acts of Prohibiting}

Directive speech acts impoliteness of prohibiting is an action from the speaker to the speech partner not to do something that the speaker or teacher does not desire. Examples of impoliteness directive speech acts prohibiting the learning of Indonesian language online include the following. (2a) "Tidak perlu, itu artinya kamu kurang memperhatikan ketentuan-ketentuan yang sudah Bu Endah tetapkan"

(No need, that means you ignore the provisions that Mrs. Endah has set).

This data includes the impoliteness of directive speech acts because the teacher as a speaker prohibits students from taking attendance. The words "tidak perlu (no need)" dan "kamu kurang memperhatikan (you don't pay attention)" as if snapped at the students who forgot to do attendance.

\section{The Impoliteness of Directive Speech Acts of Offering}

Directive speech acts impoliteness of offering in learning Indonesian language online, namely, directive speech acts aiming to offer speech partners to choose according to their wishes. Still, the way the teacher communicates is not in accordance with the rules of good manners or the teacher is considered not polite. Examples of impoliteness in the speech act of the directive giving the offer below are taken from the WhatsApp group of Indonesian teachers and students, are as follows.

(3a) "Begini saja, untuk kutipan cerpen bisa kamu tuliskan nomor paragraf dan nomor kalimat" (Tell you what, for a short story quote, you can write the paragraph number and sentence number) 
The data (3a) above includes data on impoliteness of the directive asking for speech acts because it does not contain elements of politeness that can refine speech, such as mentioning names or providing greeting words such as children. Instead, the teacher offers students to write down paragraph numbers and sentence numbers.

\section{The Impoliteness of Directive Speech Acts of Welcoming}

Impoliteness of directive speech acts as expressions of allowing or giving subtle instructions in learning Indonesian through online aims to ask the speech partner to obey something the speaker wants. The following shows the impoliteness of the speech act of the directive allowing or giving orders to other people taken from one of the schools that implements Indonesian language learning online:

(4a) "Yang bukan anggota mohon untuk keluar"

(Non-members allowed to leave the group)

Data (4a) is an example of impoliteness in directive speech acts in the form of allowing or giving orders carried out by teachers as speakers to students as speech partners. For example, the teacher asks students who are not group members to leave the WhatsApp group, but the teacher does not use soft sentences.

\section{The Impoliteness of Directive Speech Acts of Ordering}

Impoliteness of directive speech acts in words containing commands or giving orders in learning Indonesian online, namely impoliteness by teachers as speakers in providing orders to students as speech partners. Examples of impoliteness in directive speech acts that contain command words or giving orders in learning Indonesian language online are as follows:

(5a) "Motong kertas pakai cutter yang rapi. Digarisi"

(Cut paper using a neat cutter. Make lines)

(5b) "Kok sama gimana to? Dicermati dong"

(How come it's the same? Please pay close attention)

(5c) "Jangan lupa absen"

(Don't forget to give presence list)

Data (5a), (5b), and (5c) are examples of the impoliteness of directive speech acts in the form of commanding expressions. Data (5a) is that the teacher gives students orders to cut paper using a cutter and draw neat lines. Data $(5 b)$ is that the teacher asks students to look at the material on a predetermined day. Data (5c) the teacher instructs students not to forget to give presence. All of this data is included in the impoliteness of directive speech acts in learning Indonesian online because the sentences conveyed by the teacher are considered less subtle and the teacher does not 
use children's greeting words or call out students' names to give the greeting sentences delivered to students.

\section{The Impoliteness of Directive Speech Acts of Begging}

Directive speech acts of begging aim to ask for something but in a more respectful manner. In learning Indonesian language online, data is found that contains impoliteness in the directive begging as follows.

(6a) "Mohon gabung kelas di Google Classroom dengan kode naxm7wn"

(Please join classes in Google Classroom with code naxm7wn)

This data includes the impoliteness of directive speech acts because the teacher begs students to join the google classroom but does not use polite sentences. The data consists of the speech act of the requesting directive marked with the word beg or please.

\section{Directive Speech Acts of Impoliteness of Requiring}

According to Waljinah, et al. (2019), the directive demands speech act, which aims to ask earnestly or loudly for the speech partner to do what the speaker wants.

(7a) "Pastikan kuota cukup"

(Make sure the quota is sufficient)

The above data includes directive speech acts of require, but the data is not polite. Teachers need students to have sufficient quotas when participating in learning Indonesian language online.

\section{CONCLUSION}

Based on the results of research at SMA (Senior High School) A and SMA B, and SMA C, it was found that data of impoliteness of directive speech acts were (1) asking/requesting, (2) prohibiting, (3) offering, (4) welcoming, (5) command/ordering, (6) begging, and (7) requiring. Data (1a) and (1b) are examples of the impoliteness of the directive asking speech act. Data (1a) The teacher requests all students to pay attention to the implementation time of Indonesian language lessons from 07.00 to 14.00. Data (2a) the teacher as a speaker prohibits students from taking attendance. The words "tidak perlu (no need)" and "kamu kurang memperhatikan (you are not pay attention)" as if yelling at the students who forgot to do attendance. Data (3a) above includes the speech act impoliteness of the directive asking because it does not contain elements of politeness that can refine speech. Data (4a) The teacher asks students who are not members to leave the WhatsApp group, but the teacher does not use smooth sentences. Data (5a) The teacher instructs students to cut the paper using the cutter and make lines. Data (5b) the teacher asks students to look at the material. Data (5c) The teacher instructs students not to forget to attend. Data (6a) The teacher 
asks students to join the class in Google Classroom but does not use polite sentences. The data includes the speech act of the requesting directive marked with the word beg. Part of the seventh data (7a) stated that the teacher required students to have sufficient quotas when learning Indonesian language online.

\section{REFERENCES}

Anugrahana, A. (2020). Hambatan, Solusi dan Harapan: Pembelajaran Daring Selama Masa Pandemi Covid-19 Oleh Guru Sekolah Dasar. Scholaria: Jurnal Pendidikan Dan Kebudayaan, 10(3), 282-289. https://doi.org/10.24246/j.js.2020.v10.i3.p282-289

Creswell, J. W., Hanson, W. E., Clark Plano, V. L., \& Morales, A. (2007). Qualitative Research Designs: Selection and Implementation. The Counseling Psychologist, 35(2), 236-264. https://doi.org/10.1177/0011000006287390

Dewi, W. A. F. (2020). Dampak COVID-19 terhadap Implementasi Pembelajaran Daring di Sekolah Dasar. Edukatif: Jurnal Ilmu Pendidikan, 2(1), 55-61. https://doi.org/10.31004/edukatif.v2i1.89

Fhitri, W. . Y. (2018). Impoliteness of College Student Short Message Service Toward the Lecturer. JURNAL GRAMATIKA ; Jurnal Penelitian Pendidikan Bahasa Dan Sastra Indonesia, 4(2), 241-261. https://doi.org/https://doi.org/10.22202/JG.2018.V4i2.2666

Guion, L. A. (1969). Triangulation: Establishing the Validity of Qualitative Studies. Edis, 2002(6), 2-4. https://doi.org/10.32473/edis-fy394-2002

Hanum, N. S. (2013). Keefetifan e-learning sebagai media pembelajaran (studi evaluasi model pembelajaran e-learning SMK Telkom Sandhy Putra Purwokerto). Jurnal Pendidikan Vokasi, 3(1), 90-102. https://doi.org/10.21831/jpv.v3i1.1584

Kahfi, A. (2020). Tantangan Dan Harapan Pembelajaran Jarak Jauh Di Masa Pandemi Covid 19. Dirasah, 03(2), 137-154. https://stai-binamadani.e-journal.id/jurdir

Khair, U. (2018). Pembelajaran Bahasa Indonesia dan Sastra (BASASTRA) di SD dan MI. ARRIAYAH : Jurnal Pendidikan Dasar, 2(1), 81. https://doi.org/10.29240/jpd.v2i1.261

Locher, M. A. (2010). Introduction: Politeness and impoliteness in computer-mediated communication. Journal of Politeness Research, 6(1), 1-5. https://doi.org/10.1515/JPLR.2010.001

Locher, M. A., \& Bousfield, D. (2008). Introduction: Impoliteness and power in language. Impoliteness in Language: Studies on Its Interplay with Power in Theory and Practice, 1-14. https://doi.org/10.1515/9783110208344.0.1

Mai, K. K. K. (2017). Chapter 9 Chapter 9. Cycle, 1897(Figure 1), 44-45.

Mugford, G. (2008). How rude! Teaching impoliteness in the second-language classroom. ELT Journal, 62(4), 375-384. https://doi.org/10.1093/elt/ccm066

Pérez Hernádez, L., \& Ruiz De Mendoza, F. J. (2002). Grounding, semantic motivation, and conceptual interaction in indirect directive speech acts. Journal of Pragmatics, 34(3), 259-284. https://doi.org/10.1016/S0378-2166(02)80002-9

Prayitno, H. J. (2017). Studi Sosiopragmatik. Muhammadiyah University Press.

Rahmatilah, S., Hidayat, S., \& Apriliya, S. (2017). Media Buku Pop Up Untuk Pembelajaran Bahasa Indonesia Di Kelas Rendah. PEDADIDAKTIKA: Jurnal Ilmiah Pendidikan Guru Sekolah Dasar, 4(1), 139-148.

Searle, J. R. (1969). Speech Acts: An Essay in the Philosophy of Language. Cambridge University 
Press.

Sudaryanto. (2015). Metode dan Aneka Teknik Analisis Bahasa. Asosiasi Penerbit Perguruan Tinggi Indonesia.

Sugiarti, M., Rahayu, N., \& Wulandari, C. (2017). Analisis Ketidaksantunan Berbahasa Di Smp Negeri 18 Kota Bengkulu. Jurnal Ilmiah KORPUS, 1(2), 150-156. https://doi.org/10.33369/jik.v1i2.4112

Supriatna, E. (2020). Wabah Corona Virus Disease (Covid 19) Dalam Pandangan Islam. SALAM: Jurnal Sosial Dan Budaya Syar-I, 7(6), 555-564. https://doi.org/10.15408/sjsbs.v7i6.15247

Suyanto \& Jihad, A. (2013). Menjadi guru profesional: Strategi meningkatkan kualifikasi dan kualitas guru di era global. Esensi.

Tu, C. H., \& McIsaac, M. (2002). The Relationship of Social Presence and Interaction in Online Classes. International Journal of Phytoremediation, 21(1), 131-150. https://doi.org/10.1207/S15389286AJDE1603_2

Wijana, I. D. P. (2021). On Speech Acts. Journal of Pragmatics Research, 3(1), 14-27. https://doi.org/10.18326/jopr.v3i1.14-27 